\title{
Mineralogy, Petrography and Chemistry of Two Local Plasters, Iraq
}

\author{
Zeki A. Aljubouri \\ Department of Geology \\ College of Science \\ University of Mosul
}

\author{
Ibraheem R. Baddi \\ Oil Exploration Company \\ Ministry of Oil \\ Baghdad, Iraq
}

(Received 8/3/2011, Accepted 27/10/2011)

\begin{abstract}
The mineralogy, petrography and chemistry of two local plasters (Rasheed and Madae'n) and a dental stone were studied. Mineralogical study by x-ray diffraction spectrometer proved that the three gypsum products consist mainly of bassanite or hemihydrate $\left(\mathrm{CaSO}_{4} .0 .5 \mathrm{H}_{2} \mathrm{O}\right)$ with minor amounts of gypsum and anhydrite. The petrography of the studied thin sections, reveals that the two local plasters consist of dispersed prismatic, monoclinic crystals with ill-defined edges (bassanite of the $\beta$-hemihydrate). Dental stone consists of more packed, prismatic monoclinic crystals with well-defined and sharp edges (bassanite of the $\alpha$-hemihydrate). Compressed powders of the two local plasters improved their crystal shapes and edges and made their outlines similar to dental stone or ( $\alpha$-hemihydrate).

Chemical analyses of Rasheed and Madae'n plasters suggest that they consist of more than (96\%) bassanite with small amounts of gypsum and anhydrite. Based on these compositions, the two local plasters are suitable for moulding, casting and constructional purposes. They are unsuitable for surgical plasters.

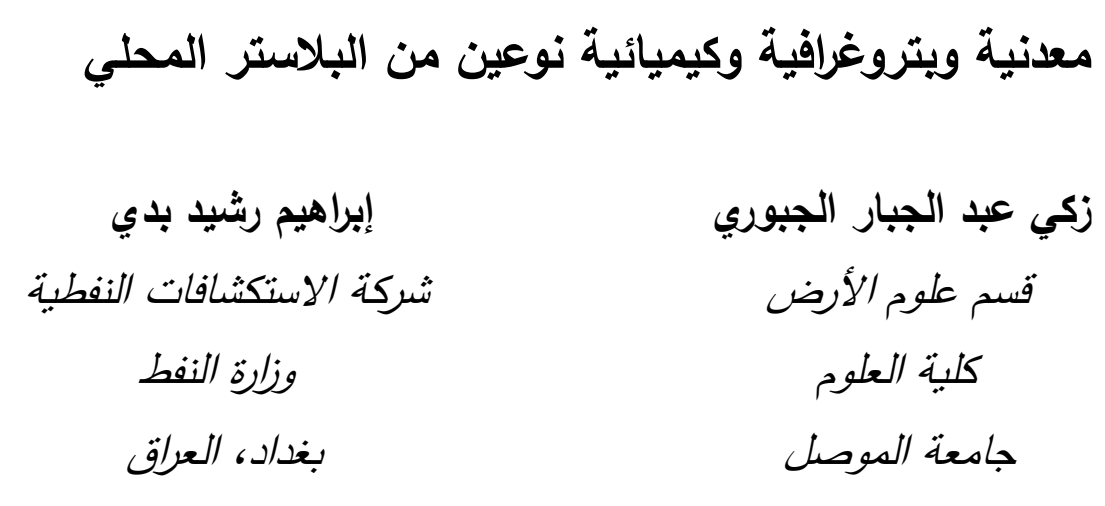

الملخص

تم دراسة معدنية وبتروغرافية وكيميائية نوعين من البلاستر (الجبس) المحلي الرشيد والمدائن وحجر

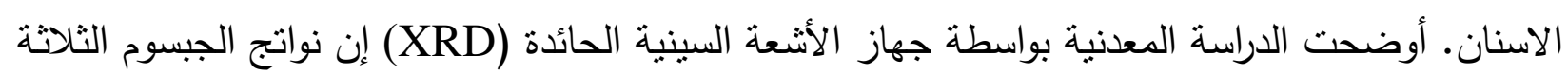

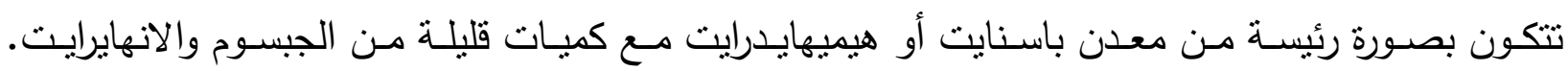


وأوضحت الدراسة البتروغرافية لمساحيق هذه النواتج بأن نوعي البلاستر المحلي يتكونان من بلورات متباعدة

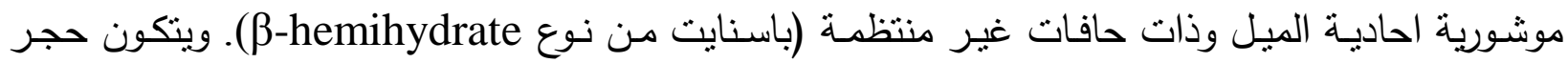

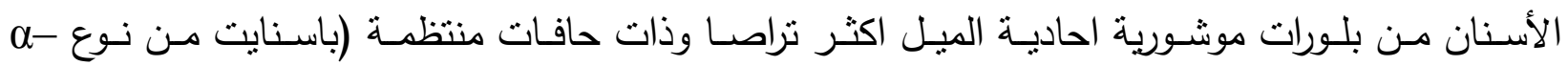
hemihydrate) • وبعد تسليط ضغط معين على مسحوق النوعين من البلاستر المحلي، تبين ان الأشكال

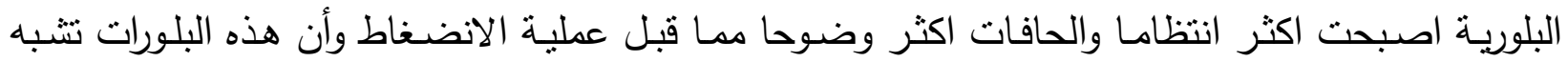

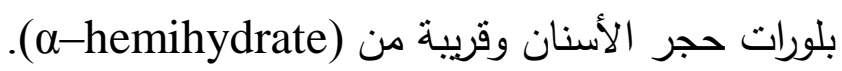
وأوضحت التحاليل الكيميائية لبلاستر الرشيد والمدائن بأنهما يتكونان من معدن باسنايت بنسبة اكبر

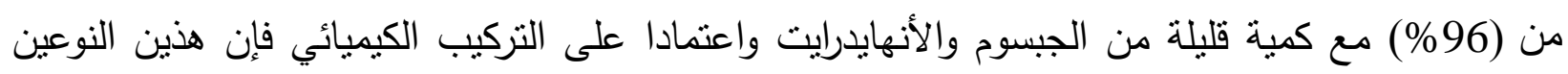

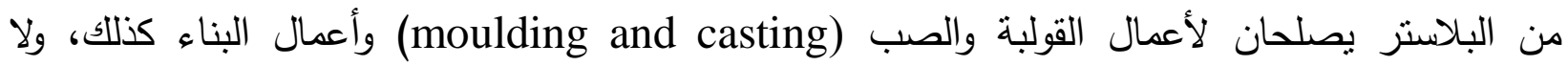
يصلحان لاستعمال البلاستر الجراحي (surgical plaster).

\section{INTRODUCTION}

A plaster is a calcined gypsum produced by heating the powdered raw material gypsum in rotary kilns at temperatures between $(120)$ and $\left(170^{\circ} \mathrm{C}\right)$ for a period of half to three hours. It is also called "Technical gyps". The use of the word "Technical" is to distinguish it from the local juss, which is also calcined gypsum but produced by rather primitive "Koor" method (Alrawas, 2002).

Three bags of "Rasheed" plaster, each weighing about $(30 \mathrm{Kg})$ were purchased from "Rasheed Gyps Factory", situated at about $(20 \mathrm{Km})$ east of Tikrit city, on the Tikrit-Kirkuk main road. The gypsum raw material for the plaster is being brought from a nearby gypsum quarry belonging to Fat'ha Formation (Middle Miocene) (Baddi, 2009). Another three bags (30 Kg each) of Madae'n plaster were purchased from the local market in Mosul city. The plaster or gyps factory is in Falloja town (55 km west of Baghdad) and the raw material is being brought from "Mohammadi-Baghdadi" quarry (Fat'ha Formation, Middle Miocene) (Al-Qaraghooli, 1989). These two local plasters (Rasheed and Madae'n) were the only available types at the time of purchase. Three kilograms of German dental stone, type (Minridul) were purchased from local medical supply bureau and used as a standard reference. All materials were purchased during August (2007).

The aim of this work is to study the mineralogy, petrography and chemistry of these two local plasters, and hence to know their proper industrial and medical applications. 


\section{DEFINITIONS}

Cast:

A cast is a rigid dressing used to immobilize a fractured, a broken bone or a soft tissue. It is made of strips of fabric impregnated with a plaster of paris (Cast Care, 2010).

\section{Gypsona:}

Is a bandage consisting of leno woven fabric impregnated with high grade, fast setting plaster of paris and is usually used to immobilize a fractured or broken bone ends in the correct alignment during the healing process (Smith and Nephew, 2010).

\section{Gypsum products:}

Materials that resulted from the calcinations of gypsum $\left(\mathrm{CaSO}_{4} \cdot 2 \mathrm{H}_{2} \mathrm{O}\right)$ and having the chemical composition of hemihydrate or the mineral bassanite $\left(\mathrm{CaSO}_{4} \cdot 0.5 \mathrm{H}_{2} \mathrm{O}\right)$. Although identical in their compositions and $\mathrm{x}$-ray diffraction peaks, they are different in their physiomechanical properties. They include three main types: local juss, plaster and dental stone and each type has several varieties.

\section{Surgical plaster:}

A high grade, fast setting plaster of paris used in ordinary casts and gypsum casts to immobilize fractured and broken bone ends in the correct alignment during the healing process.

For more definitions of gypsum products, see (Alrawas, 2002; Aljubouri and Alrawas, 2006, 2009; Abdulla, 2006; Baddi, 2009).

\section{ANALYTICAL TECHNIQUES}

The mineralogy was studied by an x-ray diffraction (XRD) spectrometer, at the Department of Geology, University of Sulaimaniya, Iraq. The spectrometer used was (EXPERT-PRO), using $\mathrm{Cu} \mathrm{K} \alpha$ radiation and Ni filter. Petrographical examinations were carried out, using a polarizing microscope, type (Swift, M.P. 1020), British made, at the Department of Geology, University of Mosul. Photographs were taken using a "Canon Digital Camera" attached to the eyepiece of the microscope.

Chemical analyses of the major oxides $\left(\mathrm{CaO}, \mathrm{SO}_{3}, \mathrm{H}_{2} \mathrm{O}^{+}\right)$and the insoluble residue (I.R.) were carried out at the Department of Geology, University of Mosul. $\mathrm{CaO}$ was volumetrically determined by titrating the calcium solution of the unknown sample with a (0.01M EDTA) solution using murexide as an indicator. $\mathrm{SO}_{3}$ was gravimetrically determined using barium chloride $\left(\mathrm{BaCl}_{2}\right)$ for the precipitation of sulphate ions (Vogel, 1961; Abbawi and Hasan, 1990). $\mathrm{H}_{2} \mathrm{O}^{+}$was 
determined by heating $(1 \mathrm{~g})$ of powdered sample in a muffle furnace at $\left(300^{\circ} \mathrm{C}\right)$ for one hour and measuring the weight loss (Aljubouri, 1972). Insoluble residue (I.R) was determined by dissolving about $(5 \mathrm{~g})$ of the sample in $(10 \% \mathrm{HCl})$ and weighing out the residue (Vogel, 1961). For the details of the mentioned analytical techniques, see Baddi (2009).

Compression of plaster was carried out at the "National Centre for Constructions and Researches, Nineva Branch, Mosul", using an Italian compression machine, type "VIA Test, DPC ", with a maximum load of (300 MPa) (Fig. 1). About $(2.5 \mathrm{~kg}$ ) of powdered plaster was placed in a cylindrical steel compression chamber, having an inner diameter of $(15 \mathrm{~cm})$ and a height of $(25 \mathrm{~cm})$. The powder was kept in, by means of two lids, each weighing about $(14 \mathrm{~kg})$ and consisting of an upper cylinder with $(14.5 \mathrm{~cm})$ diameter and a lower stem having a height of $(6 \mathrm{~cm})$ (Fig. 2). The compression chamber and the lids were supplied by (Aljubouri et al., 1999).

The compression process was carried out for about (45) seconds until constant volume of plaster was reached and held for another (15) seconds. Compressed plaster disk was broken up into small chips and crushed to pass through $(-250+125 \mu)$ sieve. This size was chosen to give the best mechanical properties (Baddi, 2009).

\section{MINERALOGY}

Figures (3, 4 and 5) show the X-ray diffraction patterns for (Rasheed and Madae'n) plasters and dental stone. Table (1) compares the (d-spacings), (2 $\theta$ 's) and intensities (\%) of these three gypsum products with (JCPDS, 1974, bassanite, card no. 24-1068). The four characteristic major peaks of the mineral bassanite in this card, at (d-spacings) of (6.01, 3.48, 3.01 and $2.80 \AA), 2 \theta(14.75,25.60,29.65$ and $\left.31.95^{\circ}\right)$ and intensities of $(100,90,100$ and $100 \%)$ respectively are all present in the two plasters and dental stone, but with different intensities, except for d $3.01 \AA$. It may be concluded that the three gypsum products consist mainly of the mineral bassanite or hemihydrate $\left(\mathrm{CaSO}_{4} \cdot 0.5 \mathrm{H}_{2} \mathrm{O}\right)$ but possibly with different concentrations. 

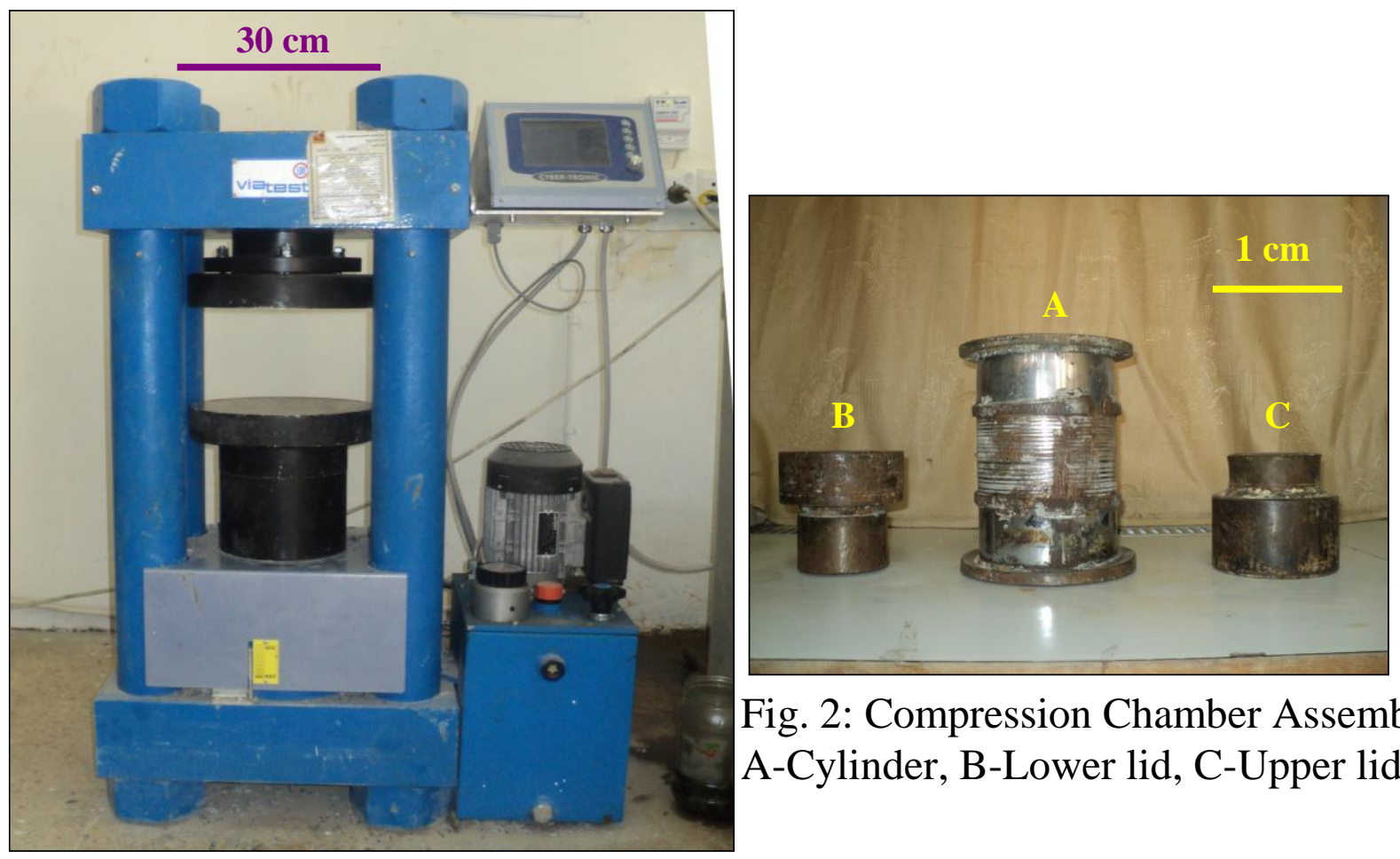

Fig. 2: Compression Chamber Assembly. A-Cylinder, B-Lower lid, C-Upper lid.

Fig. 1: Compression Machine.

With the exception of the second major peak, with intensity of (92\%) in Madae'n plaster, the first second and fourth major peaks in (JCPDS, 1974) bassanite are higher than in (Rasheed and Madae'n) plasters and dental stone (Table 1). The third peak in these three gypsum products has the same intensity of $(100 \%)$ as (JCPDS, 1974). In fact, the fourth major peak in dental stone has an intensity of only (9\%). This is possibly due to the fact that dental stones, in general, have some additives to improve their physiomechanical properties. These additives partly mask some faces from the reflection and diffraction of $\mathrm{x}$-ray, leading to a decrease in their intensities (Anderson, 1972; Anusavice, 1996). However, the lowering in intensities of gypsum products is expected, since the (JCPDS, 1974) card represents a carefully chosen standard sample, so as to give maximum characteristic intensities, but this card has an exclamation mark ( $\mathbf{i}$ ) which means that characteristic peak intensities are not always reproducible, compared with a starred card ( ).

Differences in the intensities of the four characteristic peaks of the two plasters and dental stone (Figs. 3, 4 and 5) could also be attributed to different grain sizes of these gypsum products. Table (2) shows their grain sizes distribution. It can be seen that seen that dental stone is finer than the other two having $(59.35 \%)$ grain size between $(-125$ to $-45 \mu)$ followed by Rasheed plaster $(50.63 \%)$ and $(37.6 \%)$ for Madae'n plaster. According to Kauffer et al. (2002) and Chisholm (2005) an increase of (one micron) in the diameter of quartz grain will lead to an increase of about (2-3\%) in intensity per unit mass. Different grain sizes 
lead to different surface area and perhaps different faces exposed to $\mathrm{x}$-rays which result in different intensities. Variable concentrations of the main constituent bassanite, in the three gypsum products could also lead to different peak intensities.

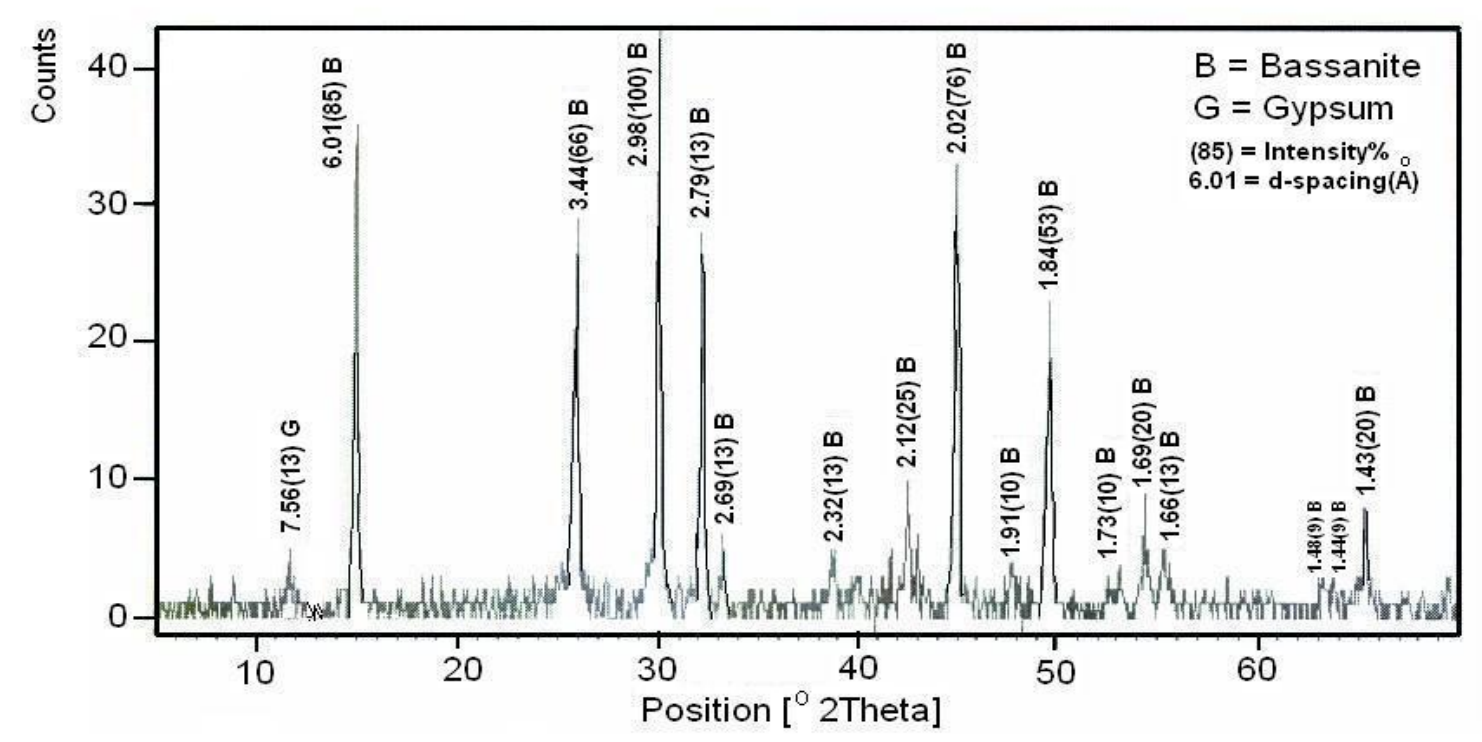

Fig. 3: X-Ray Diffraction Peaks for Rasheed Plaster.

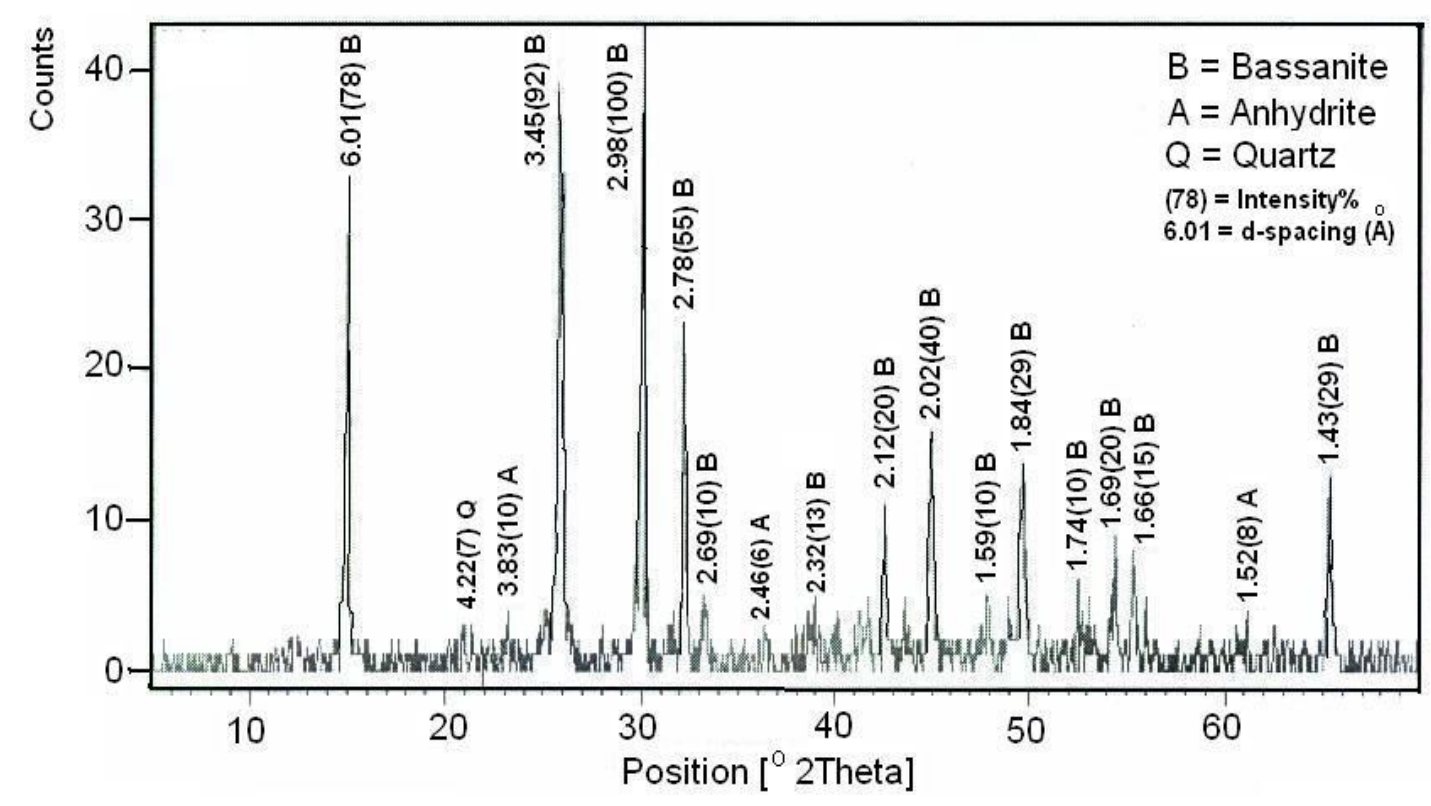

Fig. 4: X-Ray Diffraction Peaks for Madae'n Plaster. 


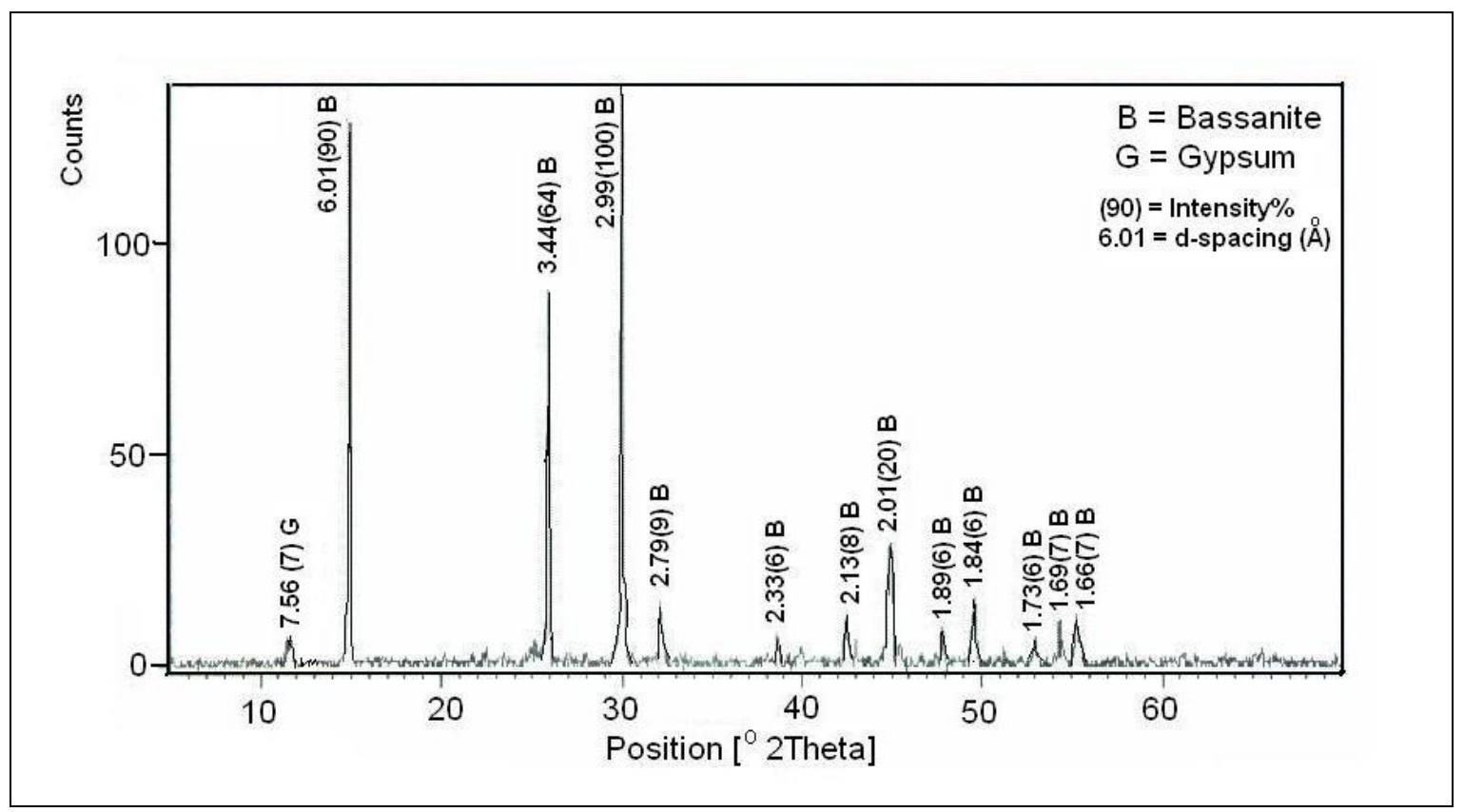

Fig. 5: X-Ray Diffraction Peaks for Dental Stone.

Table 1: X-Ray Diffraction Data for (JCPDS, 1974) Bassanite, Rasheed Plaster, Madae'n Plaster and Dental Stone.

\begin{tabular}{|c|c|c|c|c|c|c|c|c|c|c|c|c|}
\hline \multicolumn{4}{|c|}{$\begin{array}{l}\text { JCPDS (1974) Bassanite } \\
\quad \text { (Card No. 24-1068) }\end{array}$} & \multicolumn{3}{|c|}{ Rasheed Plaster } & \multicolumn{3}{|c|}{ Madae'n Plaster } & \multicolumn{3}{|c|}{ Dental Stone } \\
\hline d $\AA$ & $I_{0}$ & hkl & $2 \theta$ & $\AA$ & $\mathbf{I} / \mathbf{I}_{\mathbf{0}}$ & $2 \theta$ & $\AA$ & $\mathbf{I} / \mathbf{I}_{\mathbf{o}}$ & $2 \theta$ & d $\AA$ & $\mathbf{I} / \mathbf{I}_{\mathbf{0}}$ & $2 \theta$ \\
\hline 6.01 & 0 & & 5 & & $2 \pi$ & 14.75 & & 78 & .75 & 01 & 90 & .75 \\
\hline 48 & 90 & & & & & 90 & & & 82 & 44 & 4 & \\
\hline 3.01 & 0 & 00 & & & & 9 & & 100 & 99 & 2.99 & 100 & \\
\hline .80 & 100 & & & & & 8 & & & 0 & 2.79 & 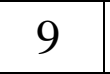 & 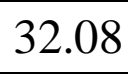 \\
\hline 2.71 & 30 & & & & & 1 & & & & 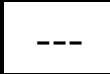 & & \\
\hline 2.34 & 20 & & & & & & & & & 3 & & .00 \\
\hline 2.14 & 24 & & & & & 0 & & & סJ & 2.13 & 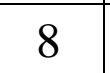 & .40 \\
\hline 2.01 & 10 & 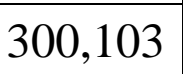 & & & & 17 & & 40 & 87 & .01 & 20 & .10 \\
\hline 1.91 & 30 & & & & & 1 & & & 3.15 & 1.89 & 5 & 3.15 \\
\hline 1.85 & 100 & & & & & 49.54 & & 29 & 49.54 & 1.84 & 10 & 49.54 \\
\hline 1.74 & 30 & 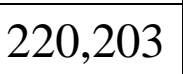 & 52.60 & & & 52.92 & & 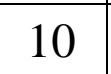 & 52.60 & 1.73 & 6 & 52.92 \\
\hline 1.70 & 70 & & 53. & & & 54.28 & & 20 & 4.28 & 1.69 & 7 & 4.28 \\
\hline 1.67 & 40 & & 54.98 & & & 55.34 & & 15 & 55.34 & 1.66 & 1 & 55.34 \\
\hline 1.53 & 10 & $U 4,222$ & & & & --- & & - & 60.95 & $\begin{array}{l}-- \\
--\end{array}$ & --- & --- \\
\hline 1.44 & 10 & 114 & 64.74 & 1.43 & 20 & 65.25 & 1.43 & 29 & 65.25 & --- & --- & --- \\
\hline
\end{tabular}


Table 2: Grain Size Analyses for Rasheed and Madae'n Plasters.

\begin{tabular}{|c|c|c|c|}
\hline \multirow{2}{*}{$\begin{array}{c}\text { Sieve Size Range } \\
(\text { micron, } \boldsymbol{\mu})\end{array}$} & \multicolumn{3}{|c|}{ Weight Retained \% } \\
\cline { 2 - 4 } & Rasheed Plaster & $\begin{array}{c}\text { Madae'n } \\
\text { Plaster }\end{array}$ & Dental Stone \\
\hline+250 & 2.6 & 5.2 & 0.1 \\
\hline$-250,+125$ & 46.8 & 57.2 & 40.6 \\
\hline$-125,+90$ & 27.8 & 17.9 & 30.3 \\
\hline$-90,+45$ & 21.5 & 18.3 & 25.4 \\
\hline-45 & 1.3 & 1.4 & 3.6 \\
\hline
\end{tabular}

\section{ACCESSORY MINERALS}

The accessory minerals detected by x-ray diffraction spectrometer are gypsum (in Rasheed plaster and dental stone), anhydrite and quartz (in Madae'n plaster). Gypsum appears at its major characteristic peak, with very low intensity of (7\%) only at (d-spacing) of (7.56 $\AA$ ) (Figs. 3 and 5. Anhydrite appears in Madae'n plaster at three small peaks with (d-spacings) of (3.87, 2.46 and $1.52 \AA$ ) and intensities of $(10,7$ and 8$)$ respectively. It is possible that the characteristic major peak of anhydrite at (d-spacing) of $(3.49 \AA)$ is overlapped by bassanite second major peak of (d-spacing) (3.48 $\AA$ ) and intensity of (90\%) (left shoulder) (Fig. 4). Quartz appears at one peak only with d-spacing of $(4.23 \AA)$ and $2 \Theta$ of $\left(21^{\circ}\right)$ and intensity of only $(7 \%)$. Its major peak at $(3.34 \AA)$ and $2 \Theta$ of $\left(26.70^{\circ}\right)$ is overlapped by bassanite second major peak ( $\mathrm{d}=3.48 \AA$ ) at the higher right shoulder (Fig.4).

The presence of gypsum $\left(\mathrm{CaSO}_{4} \cdot 2 \mathrm{H}_{2} \mathrm{O}\right)$ and anhydrite $\left(\mathrm{CaSO}_{4}\right)$ in gypsum products (plaster and dental stones) is usually attributed to the low temperature of calcination or short calcination time resulting in an unburnt of some of the raw material gypsum, or to overheating (over calcination) or long heating time resulting in an overburnt gypsum or anhydrite (Aljubouri and Alrawas, 2006). The presence of smaller amouts of quartz is usually attributed to the marl impurities in gypsum. These mainly consist of clay minerals and quartz (Al-Hadeedi, 2010). 


\section{PETROGRAPHY}

The results of petrographical study, using a polarizing microscope are shown in plates $(1-5)$.

Plate (1) shows that dental stone consists of rather elongated well-defined crystals, with clear, sharp edges and visible cleavage. These properties are for bassanite, type $\alpha$-hemihydrate where all dental stones consist of.

On the other hand, plates ( 2 and 4 ) show the outlines of grains of Al-Rasheed and Madae'n plasters (before compression) to consist of irregular crystals with ill-defined edges and some of the grains are sub-rounded and enveloped by iron oxide from marl impurities. These properties are for bassanite of the $\beta$-type (McCabe, 1985; Anusavice, 1996). These findings are in full agreement with that of Alrawas (2002).

However, after compression by applying a load of 200 tons (Baddi, 2009), a considerable part of crystals of the two plasters have become much more uniform in their outlines, with well-defined edges and similar to dental stone crystals (Plates 3 and 5). This means that compression of the powdered plaster improves its crystal forms and make them similar to $\alpha$-hemihydrate, leading to perhaps better physical properties. The improvement in the crystal outlines is perhaps due to recrystallization under the confined pressure, facilitated by the excellent property of flowage and creep of sulphate rocks (Klimchouk and Andrejchuk, 1996).

The (XRD) card for bassanite, number (24-1068) of (JCPDS, 1974) gives the mineral a hexagonal system. However, the petrographical study shows that the crystals of the three gypsum products, that is the dental stone, Rasheed and Madae'n plasters (compressed samples) are elongated, four-sided crystals with an angle between the long and short edges about $\left(57-62^{\circ}\right)$. These properties are for monoclinic and not hexagonal crystals. The crystals are very similar to gypsum (monoclinic) crystals.(Philips and Griffen,1981). Moreover, Minicryst (2010) has given a monoclinic symmetry for bassanite (Table 3) with space group (I2), that is body centered monoclinic unit cell (I), belonging to the sphenoidal class (2) (Hurlbut and Klein, 1977).

\section{CHEMISTRY}

Table (4) shows the average chemical analyses for (Rasheed and Madae'n) plasters and dental stone, compared with (Ahlia and Malaj) plasters of (Aljubouri and Alrawas, 2006) and the theoretical bassanite or hemihydrate $\left(\mathrm{CaSO}_{4} \cdot 0.5 \mathrm{H}_{2} \mathrm{O}\right)$. The $\left(\mathrm{CaO}\right.$ and $\left.\mathrm{SO}_{3}\right)$ averages of the five gypsum products are close to the theoretical bassanite, indicating that they consist mostly of bassanite as has already been proved by (XRD) analyses. However, these gypsum products (with the exception of Madae'n plaster with lower $\mathrm{H}_{2} \mathrm{O}^{+}$) have highewr $\left(\mathrm{H}_{2} \mathrm{O}^{+}\right)$ than the theoretical bassanite, indicating the presence of gypsum in them and anhydrite in Madae'n plaster. This is also has been proved by (XRD) analyses. (Figs. 3, 4 and 5) 
Table 3: Bassanite Information Card (MINICRYST, 2010).

\begin{tabular}{|c|c|}
\hline BASSANITE & \multirow{3}{*}{$\begin{array}{l}\text { Wavelength for calculated Powder } \\
\text { Diffraction Pattern } \quad \mathrm{Cu}=1.54056 \AA\end{array}$} \\
\hline & \\
\hline Card No. & \\
\hline Specification & $2 \theta$ Range \\
\hline$\left(\mathrm{CaSO}_{4}\right)_{2} \cdot \mathrm{H}_{2} \mathrm{O}$ & JCPDS (1974) Card No. \\
\hline Symmetry Class & Unit Cell Volume $\AA^{3}$ \\
\hline Space Group & Molar Volume $\mathrm{cm}^{3} / \mathrm{mol} . \quad$ Vm $=106.02$ \\
\hline $\begin{array}{l}\text { Unit Cell Parameters } \begin{array}{r}\mathrm{a}-12.0317 ; \\
\mathrm{b}=6.9272 ; \\
\mathrm{c}=12.6711 ; \beta=90.270\end{array}\end{array}$ & $\mathrm{X}$-ray Density, $\mathrm{g} / \mathrm{cm}^{3}$ \\
\hline Number of Formula Unit & $\boldsymbol{\mu}=192.189$ \\
\hline $\begin{array}{l}\text { Number of Atomic Positions } \\
\text { Per full Unit Cell }\end{array}$ & $\begin{array}{l}\text { Mass attenuation coefficient, } \\
\mathrm{cm}^{2} / \mathrm{g} \quad \boldsymbol{\mu} / \boldsymbol{\rho}=70.200\end{array}$ \\
\hline
\end{tabular}

The $\left(\mathrm{CaO} / \mathrm{SO}_{3}\right)$ ratio for Rasheed, Madae'n and Malaj plasters and dental stone is slightly higher than the theoretical (0.700) indicating the presence of small amounts of dolomite in these gypsum products. Malaj plaster contains no dolomite since the $\left(\mathrm{CaO} / \mathrm{SO}_{3}\right)$ ratio is equal to $(0.700)$. Gypsum and its products often contain small amounts of dolomite, which is thought to be due to local dolomitization (Alrawas, 2002; Aljubouri and Alrawas, 2006; Baddi, 2009; AlHadeedi, 2010).

Bassanite $\left(\mathrm{CaSO}_{4} \cdot 0.5 \mathrm{H}_{2} \mathrm{O}\right)$ is calculated in (Table 4) by multiplying $\left(\mathrm{SO}_{3} \%\right)$ by (1.8129). This oxide is used rather than $(\mathrm{CaO})$ since the latter contains excess $(\mathrm{CaO})$ in dolomite. $\left(\mathrm{H}_{2} \mathrm{O}^{+}\right)$can not be used since its quality is controlled by calcination process. Insoluble residue (I.R.) represents marl impurities and consists mainly of clay minerals, quartz and iron oxides. From the chemical analysis of the insoluble residue, its constituent oxides could be calculated as follows: Total $\mathrm{SiO}_{2}=$ I.R.x0.578; $\quad \mathrm{Al}_{2} \mathrm{O}_{3}=$ I.R.x0.1376; Total $\quad \mathrm{Fe}_{2} \mathrm{O}_{3}=\mathrm{I} \cdot \mathrm{R} \cdot \mathrm{x} 0.1055 ; \quad$ Total $\mathrm{MgO}=\mathrm{I} . \mathrm{R} . \mathrm{x} 0.1789$ (Aljubouri and Alkawaz, 2008). 
Table 4: Average Chemical Analyses of (Rasheed and Madae'n) Plasters and Dental Stone compared with Ahlia and Malej Plasters of Aljubouri and Alrawas (2006).

\begin{tabular}{|c|c|c|c|c|c|c|c|c|c|}
\hline \multirow{2}{*}{$\begin{array}{c}\text { Oxide } \\
(\%)\end{array}$} & \multicolumn{6}{|c|}{ Present Study } & \multicolumn{2}{|c|}{$\begin{array}{l}\text { Aljubouri and } \\
\text { Alrawas (2006) }\end{array}$} & \multirow{2}{*}{$\begin{array}{c}\text { Theoretical } \\
\text { Bassanite } \\
(\mathbf{n = 1})\end{array}$} \\
\hline & $\begin{array}{c}\text { Rashee } \\
\text { d } \\
\text { Plaster } \\
(\mathbf{n}=15) \\
\end{array}$ & $\sigma$ & $\begin{array}{c}\text { Madae'n } \\
\text { Plaster } \\
(\mathbf{n}=15)\end{array}$ & $\sigma$ & $\begin{array}{c}\text { Dental } \\
\text { Stone } \\
(n=3)\end{array}$ & $\sigma$ & $\begin{array}{c}\text { Ahlia } \\
(n=15)\end{array}$ & $\begin{array}{l}\text { Malej } \\
(n=15)\end{array}$ & \\
\hline $\begin{array}{l}\mathrm{CaO} \\
\mathrm{SO}_{3} \\
\mathrm{H}_{2} \mathrm{O}^{+} \\
* \mathrm{SiO}_{2} \\
* \mathrm{Al}_{2} \mathrm{O}_{3} \\
* \mathrm{Fe}_{2} \mathrm{O}_{3} \\
* \mathrm{MgO}\end{array}$ & $\begin{array}{c}37.44 \\
53.17 \\
6.45 \\
1.26 \\
0.30 \\
0.23 \\
0.29\end{array}$ & $\begin{array}{c}1.7 \\
0.87 \\
0.25\end{array}$ & $\begin{array}{c}38.26 \\
53.97 \\
5.46 \\
1.10 \\
0.26 \\
0.20 \\
0.33\end{array}$ & $\begin{array}{l}1.52 \\
1.60 \\
0.58\end{array}$ & $\begin{array}{c}37.86 \\
53.78 \\
6.51 \\
0.97 \\
0.23 \\
0.18 \\
0.30\end{array}$ & $\begin{array}{c}1.9 \\
1.3 \\
0.64\end{array}$ & $\begin{array}{c}37.62 \\
53.93 \\
7.20 \\
0.50 \\
0.12 \\
0.09 \\
0.15\end{array}$ & $\begin{array}{c}37.84 \\
54.29 \\
6.70 \\
0.45 \\
0.10 \\
0.08 \\
0.14\end{array}$ & $\begin{array}{c}38.64 \\
55.16 \\
6.20 \\
--- \\
--- \\
--- \\
---\end{array}$ \\
\hline Total & 99.24 & & 99.58 & & 99.83 & & 99.61 & 99.60 & 100.00 \\
\hline $\begin{array}{l}\mathrm{CaO} / \mathrm{SO}_{3} \\
\# \mathrm{CaSO} \mathrm{SO}_{4} \cdot 0.5 \mathrm{H}_{2} \mathrm{O} \\
\text { I.R. }\end{array}$ & $\begin{array}{c}0.70416 \\
96.39 \\
2.18\end{array}$ & & $\begin{array}{c}0.7089 \\
97.84 \\
1.89\end{array}$ & & $\begin{array}{c}0.7040 \\
97.50 \\
1.68\end{array}$ & & $\begin{array}{c}0.7017 \\
97.77 \\
0.86\end{array}$ & $\begin{array}{c}0.700 \\
98.42 \\
0.77\end{array}$ & $\begin{array}{c}0.700 \\
100.00 \\
0.00\end{array}$ \\
\hline
\end{tabular}

$\mathrm{n}=$ number of samples; * Calculated from insoluble residue (I.R); \# $\mathrm{CaSO}_{4} \cdot 0.5 \mathrm{H}_{2} \mathrm{O}$ $=\mathrm{SO}_{3} \% \times 1.8129 ; \sigma=$ standard deviation.

\section{APPLICATION}

There are two main applications of plasters in general; the first includes making moulds and casts, and the second includes constructional and building materials. Examples of the first are pottery moulds, dental plaster, lithographers, modelers, museums for making copies of rare specimens, sculptors and surgical plasters. Examples of the second are wall plasters, plaster boards, stucco (decorated false ceiling) and cementing material replacing Portland cement (Robertson, 1961; Alrawas, 2002; Aljubouri and Alrawas, 2006, 2009). 
Moulding, casting and constructional plasters, with the exception of surgical plaster, are applied without contact with any part of human body and therefore do not have to be of high purity. On the other hand, surgical plaster (e.g. gypsona) applied for the immobilization of fractured and broken bones and hence it has to be in contact with human skin. High purity is required for this type of gypsum product.

Examining Table (5) which shows the average chemical compositions of the three moulding and constructional plasters and one surgical plaster and comparing them with Rasheed and Madae'n plasters of the present study(Table 4) reveals that the average chemical compositions of these two local plasters are within those for moulding, casting and constructional applications and therefore they could be used for these purposes. However, these two local plasters do not match the compositional requirements for surgical plaster, despite the fact that they both consist of more than $(96 \%)$ hemihydrate $\left(\mathrm{CaSO}_{4} \cdot 0.5 \mathrm{H}_{2} \mathrm{O}\right)$. They have more $\mathrm{SiO}_{2}$, $\mathrm{Al}_{2} \mathrm{O}_{3}$ and $\mathrm{Fe}_{2} \mathrm{O}_{3}$ than surgical plaster and these oxides called the "deleterious" or "objectionable" constituents (Singh, 2006).

On the other hand, Ahlia and Malej plasters are very close in their average chemical compositions to surgical plaster. They have less $\mathrm{SiO}_{2}$ and $\mathrm{MgO}$ and more $\mathrm{Al}_{2} \mathrm{O}_{3}$ and $\mathrm{Fe}_{2} \mathrm{O}_{3}$ (Tables 4 and 5). The compositional requirements for surgical plaster of Singh (2006) in Table (5) are not universal, they are for Indian standards (IS, 1973). It is possible that Ahlia and Malej plasters fulfill the compositional requirements for surgical plaster for other standards.

Table 5: Average Compositional Requirements for (Moulding, Casting and Constructional Plaster) and Surgical Plaster.

\begin{tabular}{|l|c|c|c|c|}
\hline \multirow{2}{*}{$\begin{array}{c}\text { Constituent } \\
(\text { wt \%) }\end{array}$} & \multicolumn{2}{|c|}{$\begin{array}{c}\text { Moulding, Casting and Constructional } \\
\text { Plaster }\end{array}$} & $\begin{array}{c}\text { Surgical } \\
\text { Plaster }\end{array}$ \\
\cline { 2 - 5 } & $\begin{array}{c}\text { POP } \\
\text { Supplier, } \\
\mathbf{2 0 1 0}\end{array}$ & $\begin{array}{c}\text { Khatri's, } \\
\mathbf{2 0 1 0}\end{array}$ & $\begin{array}{c}\text { Geology } \\
\text { Data, } \\
\mathbf{2 0 1 0}\end{array}$ & $\begin{array}{c}\text { Singh, } \\
\mathbf{2 0 0 6}\end{array}$ \\
\hline $\mathrm{CaSO}_{4} \cdot 0.5 \mathrm{H}_{2} \mathrm{O}$ & $92 \% \mathrm{Min}$. & $95 \% \mathrm{Min}$. & $85 \% \mathrm{Min}$. & $96 \% \mathrm{Min}$. \\
$\mathrm{SiO}_{2}$ & 0.95 & 0.95 & 6.0 & 0.83 \\
$\mathrm{Al}_{2} \mathrm{O}_{3}$ & 0.70 & 0.70 & 0.83 & 0.08 \\
$\mathrm{Fe}_{2} \mathrm{O}_{3}$ & 0.30 & 0.30 & 0.36 & 0.04 \\
$\mathrm{MgO}$ & 0.10 & 0.10 & 1.79 & 0.59 \\
\hline
\end{tabular}




\section{CONCLUSIONS}

The present study concludes at:

1. There is no marked differences in x-ray diffraction peak patterns between dental stone and the two local plasters Rasheed and Madae'n. The three gypsum products consist mainly of hemihydrite $\left(\mathrm{CaSO}_{4} \cdot 0.5 \mathrm{H}_{2} \mathrm{O}\right)$ or bassanite.

2. Accessory minerals revealed by (XRD) and inferred from chemical analyses are gypsum, anhydrite, quartz and dolomite.

3. Under the microscope, dental stone consists of well-defined monoclinic crystals of $\alpha$-hemihydrate. Rasheed and Madae'n plasters consist of irregular and illdefined monoclinic crystals of $\beta$-hemihydrate. Subjecting the powder of these two plasters to compression, their crystals become much more regular, welldefined and similar to these of $\alpha$-hemihydrate.

4. Chemical compositions of Rasheed and Madae'n plasters proved that they could be used for moulding, casting and constructional purposes. They are unsuitable as surgical plasters.

\section{REFERENCES}

Abbawi, S. A. and Hasan, M. S., 1990. Environmental Practical EngineeringWater Tests. University of Mosul, 296p. (In Arabic).

Abdulla, M. A., 2006. Evaluation of some Properties of Gypsum Products and Acrylic Resin by the Use of some Additives and Mmicrowave Technique. Unpub. M.Sc. Thesis, College of Dentistry, University of Mosul, 169 p.

Alhadeedi, B. A. M., 2010. Mineralogy, Petrography and Geochemistry of Gypsum Rocks in Gercus and Fat'ha Formations: A Comparative Study. Unpub. M.Sc. Thesis, University of Mosul, 117p., (In Arabic).

Aljubouri, Z. A. and Al-Kawaz, H. A., 2008. Geochemistry of Marl Sediments within Fat'ha Formation at Selected Locations, Northern Iraq. Iraqi Jour.of Earth Science, Vol. 1, No. 2, pp. 27 - 46.

Aljubouri, Z. A. and Alrawas, A. M., 2006. The Petrography and Mineralogy of Technical Plaster and Local Juss. Iaqi Jour. Earth Science, Vol. 6, No. 1, pp. 1 - 11. 
Aljubouri, Z. A. and Alrawas, A. M., 2009. Physical Properties and Compressive Strength of the Technical Plaster and Local Juss. Iraqi Jour. of Earth Science, Vol.9, No.2, pp.49-58.

Aljubouri, Z. A., 1972. Geochemistry, Origin and Diagenesis of Gypsum Deposits and Associated Sediments in the East Midlands, England. Unpub. Ph.D. thesis, University of Nottingham, England, U. K., 411 p.

Aljubouri, Z. A., Al-Dabbagh, S. M., Aswad, K .J., Taqa, A. A., Chiqmaqchi, M. and Al-Khayat, I. K., 1999. Preparation of Dental Stone by Compression.

Unpub. Report, Mosul, Iraq.

Alqaraghooli, N., 1989. Mineralogical and Chemical Properties of Iraqi Gypsum. Units and Methods of Production and their Effects on the Quality of Juss and Bourak Products. Jour. Geol. Soc. Iraq, Vol. 22, No. 2, pp. 154 - 172. (In Arabic).

Alrawas, A. M. H., 2002. Study of the Chemical, Mineralogical and Physicomechanical Properties of Technical Plaster and Local Juss. Unpub. M.Sc. Thesis, Univ. of Mosul, Iraq, 83 p. (In Arabic).

Anderson, J. N., 1972. Applied Dental Materials. Blackwell, Oxford, 356p.

Anusavice, K. J., 1996. Phillip's Science of Dental Materials, $10^{\text {th }}$ Edition, Saunders Comp., pp. 185 - 208.

Baddi, I. R., 2009. The Effect of Compression and Additives on Physiomechanical

Properties of Technical Plaster. Unpub. M.Sc. Thesis, University of Mosul, 123p. (In Arabic).

Cast Care, 2010. Available at: Cast Care Information on Healthline.htm.

Chisholm, J., 2005. Comparison of Quartz Standards for X-Ray Diffraction Analysis: HSE A9950 (Sikron F600) and NIST SRM 1878. Annals of Occupational Hygiene, Vol. 49, No. 4, pp. 351 - 358.

Geology Data Info, 2010. Available at : I:IGeology Data-Info-Info Portal of Geology with Special Reference to Rajasthan.

Hurlbut, C. S. and Klein, C., 1977. Manual of Mineralogy (After J.D. Dana). Wiley and Sons, New York, USA, 532 p.

IS, 1973. Bureau of Indian Standards. Specification for Mineral Gypsum Bulletin, No. 1290, New Delhi. (In Singh, 2006).

JCPDS, 1974. Joint Committee on Powder Diffraction Standards, Card No. 24 - 1068, Calcium Sulphate Hydrate. New York, USA.

Kauffer, E.; Moulut, J. C. and Masson, A., 2002. Comparison by X-Ray Diffraction and Infrared Spectroscopy of Two Samples of $\alpha$-Quartz with NIST SRM $1878 \alpha$-Quartz. Ann. Occup. Hug., 46, 409-21.

Khatri's, 2010. Available at: I:Iwelcome to Khatri's.htm

Klimchouk, A. and Adrejchuk, V., 1966. Sulphate Rocks as an Arena for Karst Development. International Journal of Speleology, Vol. 25, pp. 1 - 9.

Majeed, S. Y., 1983. Petrography and Geochemistry of Carbonate Rocks, Fat'ha Formation, West Butma, Northern Iraq. Unpub. M.Sc. Thesis, University of Mosul, Iraq, 210 p. (In Arabic). 
McCabe, J. F., 1985. Anderson's Applied Dental Materials. $6^{\text {th }}$ Edition, Blackwell, London, UK, $178 \mathrm{p}$.

Minicryst, 2010. Available at: www.MINICRYST Information Card BASSANITE -Filesls-Carta2.htm.

Phillips, W. R. and Griffen, D.T. 1981. Optical mineralogy. Freeman, San Francisco, USA., 677p.

POP Supplies, 2010. Available at: I:IGypsum Plaster Of Paris Manufacturers, POP Supplies India.

Robertson, R. H. S., 1961. Minerals Use Guide, or Robertson's Spiders web., Cleaver-Hum Press Ltd., London, 44 p.

Singh, M., 2006. Making of Gypsum Plaster in Bhutan-An Experience. Journal of Scientific and Industrial Research, India, Vol. 65, pp. 826 - 829.

Smith and Nephew, 2010. Available at: Smith and Nephew \#.htm.

Vogel, I.N., 1961. A Textbook of Quantitative Inorganic Analyses. $3^{\text {rd }}$ edition, Longman, London, England, 1216 p. 


\section{PLATES}

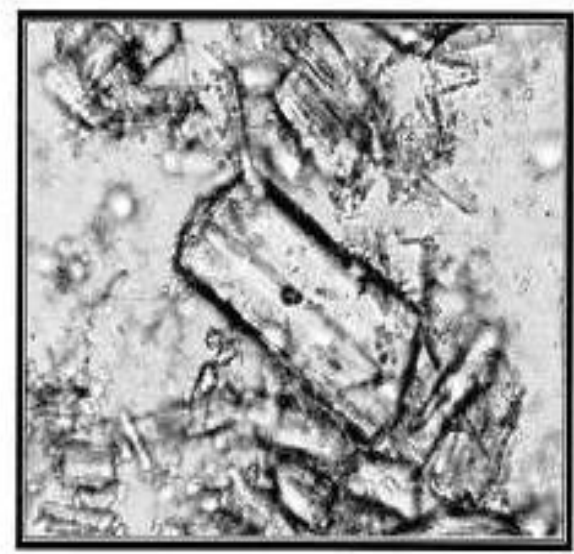

Plate (1):Dental Stone. Prismatic monoclinic crystals of Bassanite of the type $a$ - hemihydrate.
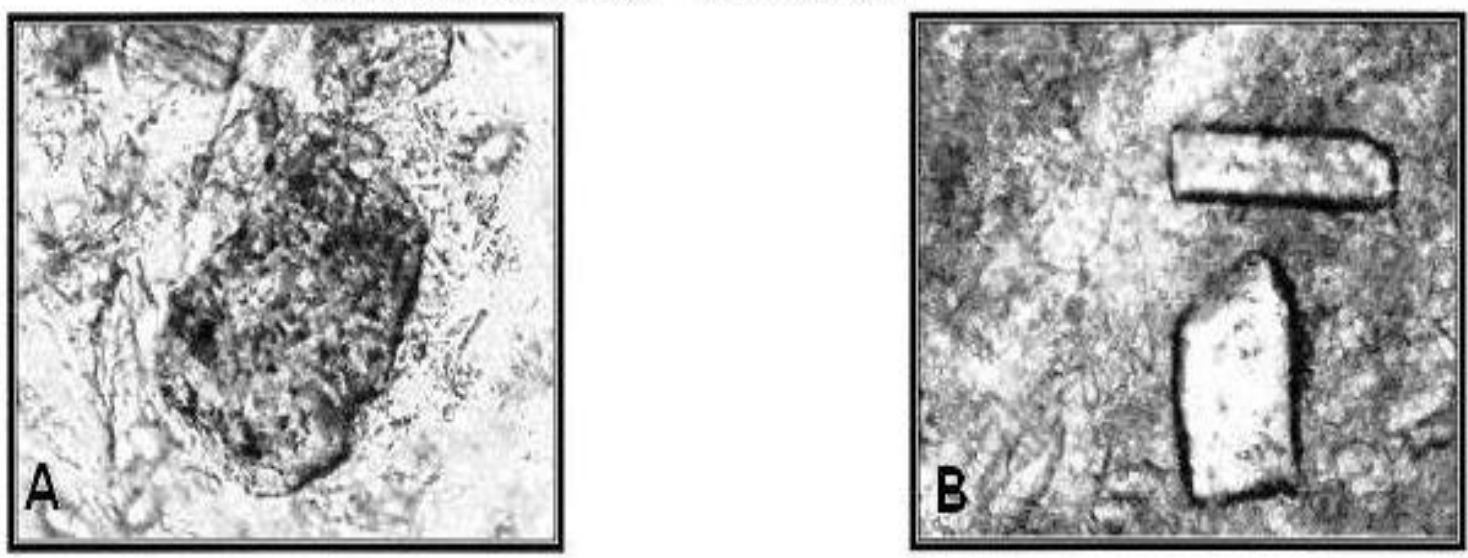

Plate (2) : Rasheed Plaster. A-Before Compression .. Crystals subrounded, with ill-defined edges of the type $\beta$ - hehihydrate . B-After Compression. Prismatic monoclinic crystals, with sharp edges of the type a-hemihydrate.
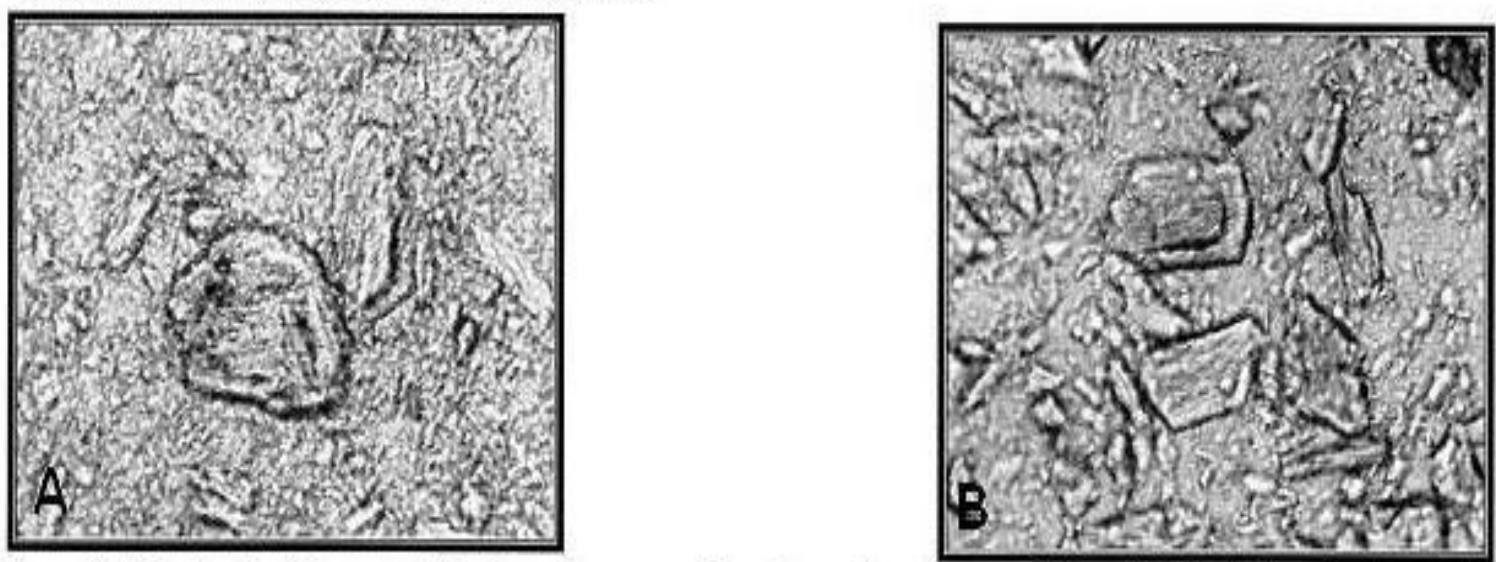

Plate (3): Madae in Plaster. A-Before Comperssion.Crystals subrounded, with ill-defined edges of the type $\beta$ - hemihydrate. B-After Compression. Prismatic monoclinic crystals, with sharp edges of the type a-hemihydrate.

All plates : Crossed polars, $1 \mathrm{~cm}=50 \mu$ 